\title{
Türk Bankacılık Sektöründe Kamu Sermayeli ve Özel Sermayeli Bankaların Kredi Verme Davranışlarındaki Asimetrinin Belirleyicileri
}

\author{
Çiğdem KURT CIHANGİR ${ }^{1}$ \\ ${ }^{1}$ Asst. Prof. Dr., Hitit University, Faculty of Economics and Administrative Sciences, Department of Business \\ Administration, Çorum, Turkey \\ Geliș Tarihi/Received: 24.01.2020 \\ Kabul Tarihi/Accepted: 28.01.2020 \\ Doi: doi.org/10.31200/makuubd.679750 \\ Araştırma Makalesi/Research Article
}

\section{ÖZET}

Bu çalışmada kamu sermayeli (KSB) ve özel sermayeli (ÖSB) bankaların kredi verme davranışlarındaki asimetrinin nedenleri ARDL Sınır Testi ile araştırılmıştır. KSB ve ÖSB’lerin kredi hacimleri ile takipteki krediler ve belirlenen makroekonomik göstergeler arasında kısa ve uzun dönemde ilişki olduğu tespit edilmiştir. Uzun dönemde KSB'lerin kredi hacminde etkili olan tek değişken takipteki kredilerken; ÖSB'lerin kredi hacminde takipteki kredilerle birlikte döviz kuru ve ekonomik güven endeksinin de etkili olduğu belirlenmiştir. Buna göre KSB'lerin aktif karş1-konjontrürel (döngüsel) rol üstlendikleri söylenebilir.

Anahtar kelimeler: Kamu Sermayeli Bankalar, Özel Sermayeli Bankalar, Kredi Verme Davranışı.

JEL Sınıflaması: E44, G21, G28.

\section{Determinants of Asymmetry in Lending Behavior of Public-Owned and Privately-Owned Banks in Turkish Banking Sector}

\section{ABSTRACT}

In this study the causes of asymmetry in lending behaviors of public-owned banks(PuBs) and privately-owned (PrBs) banks are investigated with ARDL Boundary Test. It is find that there is a short and long term relationships between the credit volumes of the public-owned banks and privately-owned banks and the non-performing loans and the identified macroeconomic indicators. In the long term, the only variable that has an impact on the credit volume of publicowned banks is non-performing loans; although, the variables that are effective in the credit

* Sorumlu yazar/Corresponding author

E-mail/e-ileti: kurt_cigdem@yahoo.com 
volume of the privately-owned banks are non-performing loans, exchange rate and the economic confidence index. Accordingly, it can be said that public-owned banks play an active counter-cyclical role.

Keywords: Public-Owned Banks, Privately-Owned Banks, Lending Behavior.

JEL Classification: E44, G21, G28.

\section{GİRISS}

Kredi piyasalarının standart piyasalardan iki önemli farklılığı vardır (Bakır-Yiğitbaş, 2012): Birincisi, kredi piyasasında kredi talep eden ile kredi arz eden arasında simetrik bilginin olmaması, ikincisi ise bir birey ya da işletme tarafından bugün alınan bir kredinin geri ödemesinin gelecekte vaat edilen bir tarihte yapılması nedeniyle ortaya çıkabilecek kredinin geri ödenmemesi olasılığıdır. Dolayısıyla, her ne kadar banka kredi kullandırırken gerekli analizleri yapsa da sistemin doğasında olan asimetrik bilgi nedeniyle finanse ettiği yatırım, proje ya da kişi veya firma hakkında tam bilgiye sahip değildir. Bankaların üstlendikleri bu risk gelecekteki nakit akışlarının tam ve zamanında gerçekleşmemesi riskini de beraberinde getirir. Sonuç itibariyle, bankanın asimetrik bilgiden kaynaklanan bir kredi verme davranışı söz konusudur. Bankaların kredi verme davranışı dış şoklardan, makroekonomik yapıdan ve sektöre ve/veya bankaya özgü özelliklerden etkilenebilir. Dış şoklar ve makroekonomik yapı bankalar için sistematik risk unsurları olarak düşünülebilir. Örneğin, kur şokları ya da enflasyon, ekonomik büyüme, istihdam seviyesi vb, göstergeler bankaların kredi verme davranışlarını etkileyen faktörlerdir.

Bir finansal kriz ya da kur şoku durumunda bankaların takipteki kredilerinin artması beklenen bir durumdur. Reinhart ve Kaminsky (1999) ve Reinhart ve Rogoff (2011), takipteki kredilerdeki büyük bir artışın finansal krizlerin güvenilir bir öncü göstergesi olduğunu belirtmişlerdir. Bir bankacılık krizi sonucunda bir taraftan bankaların kredi hacmi düşmekte ve bankalar aktif yapılarını daha az kredi verecek şekilde planlamaktadırlar (Demirgüç-Kunt vd., 2006), diğer taraftan kredi arzındaki düşüşe bağlı olarak GSYH düşmektedir (Dell'Ariccia vd., 2008). Mishkin (2000: 202) de finansal kriz dönemlerinde, finansal aracıların, fonların verimli yatırımlara aktarılması olarak açıklanan temel işlevini etkin bir şekilde yerine getirememeleri nedeniyle iktisadi faaliyetlerde daralma yaşandığını belirtmiştir. Benzer biçimde yüksek enflasyonun olduğu ekonomilerde de artan kredi riski nedeniyle takipteki krediler artmaktadır 
(Parasız, 2000: 126; Demirgüç-Kunt ve Detragiache, 1998). Takipteki kredilerin artması aşağıda sıralanan nedenlerle bankaların kredi arzını kısmalarına neden olmaktadır:

i) Kredinin takibe düşen kısmı için ayrılan karşılıkların yarattığı ek kaynak maliyeti

ii) Kredinin takibe düşmesiyle birlikte riskinin artmasının, düzenleyici otoritenin belirlediği sermaye yeterlik ihtiyacını artırması,

iii) Takipteki kredileri artan; yani aktif yapısı bozulan bankanın riskinin artmasına bağlı olarak fonlama maliyetinin nispeten yükselmesi (bu kaynak maliyeti artışını kredi faiz oranına yansıtacağı için)

bankaların kredi verme davranışını olumsuz etkilemektedir.

Bir ekonomide bankaların kredi verme davranışının aynı olmamasında banka sahiplerince belirlenen iş modelinin de etkisi vardır. Buna göre, özel sermayeli bankalar (ÖSB) karı en çoklamaya yönelik iş modellerini belirlerken, kamu sermayeli bankalar (KSB) sosyal refahı sağlamaya ve/veya sürdürmeye yönelik iş modelleri belirlemektedirler (Behr vd., 2013). Aynı makroekonomik ortamda faaliyet gösteren ÖSB ve KSB'lerin kredi verme davranışlarındaki bu farklılığın birçok nedeni olabilir. Birincisi La Porta, Lopez-de-Silanes ve Shleifer'in (2002) belirttikleri gibi bankaların kamu sahipliğinde olmaları yaygın bir durumdur ${ }^{1}$. İkincisi, kamunun bankacılık sektöründe varlığının sonuçları konusunda tam bir fikir birliği yoktur. Buna göre bazı araştırmacılar kamu bankalarının sektörde bulunmalarının ekonomik kalkınma ve sosyal refah açısından olumlu sonuçları olduğunu savunurken (Stiglitz, 1993; Burgess ve Pande, 2005); bazı araştırmacılar da siyasi etki, verimsiz kredi tahsisi gibi olumsuz sonuçları olduğunu savunmaktadırlar (La Porta ve diğerleri, 2002; Sapienza, 2004; Behr ve diğerleri, 2013). Üçüncüsü, kamunun bankacılık sektörüne katılmasının sonuçları ilgili ülkenin yasal ve siyasi kurumlarına göre değişmektedir (Dinç, 2005; Körner ve Schnabel, 2011). Micco ve Panizza (2006), KSB'lerin kriz yıllarında kredi verme davranışlarındaki değişikliklerin nedenlerini aşağıdaki gibi sıralamışlardır:

i) KSB'ler, hükümet politikasının bir parçası olarak kredi piyasasını dengelemeye çalışırlar,

\footnotetext{
${ }^{1}$ Devlet bankacılık sektöründe üzerinde üç farklı yolla bulunabilir. Bunlar: bankalarda doğrudan devlet mülkiyeti, garantiler yoluyla devlet sponsorluğu veya devlet bazlı borç verme veya tasarruf programlarıdır.
} 
ii) tasarruf sahipleri tasarruflarını güvenli kabul ettikleri bu bankalara yönlendirdikleri için KSB'lerin nispeten daha fazla borç verilebilir fonları vardır,

iii) bu bankaların yöneticileri şoklara tepki vermekte yavaş olabilirler

iv) politikacılar, yeniden seçilme olasılıklarını artırmak için bankaların kredi verme davranışını etkileyebilirler.

Tasarruf açığg olan bir ülke olarak Türkiye'de bankacılık sektörü temelli bir finansal sistemin olduğunu söylemek mümkündür. Dolayısıyla banka kredileri ile ekonomik büyüme arasında doğrudan bir ilişki kurulabilir (Öztürkler ve Çermikli, 2007; Mercan, 2013; Alihodžić ve Ekşi, 2018; Kurt Cihangir, 2019). Şekil 1'de Türkiye'de kredi büyümesi ile sanayi üretim endeksinin (SÜE) y1llar itibariyle değerleri verilmiştir. Ekonomik büyüme göstergesi çeyrek dönemlik verilerle yayımlandığı için onunla en yüksek korelasyona (\%83) sahip olan ve aylık frekansta yayımlanan sanayi üretim endeksi alınmıştır. Şekil 1 incelendiğinde kredi büyümesi ile SÜE'nin genel itibariyle paralel bir seyir izlediği; ancak son dönemde aralarında bir makas oluştuğu görülmektedir. Buna göre, ekonomik büyümeyi temsilen kullanılan SÜE'de nispeten iyileşme olmasına karşın bankaların kredi büyümesi bu iyileşmeye önce eşlik etmemiş sonrasında kredi büyümesi artmaya başlamıştır.

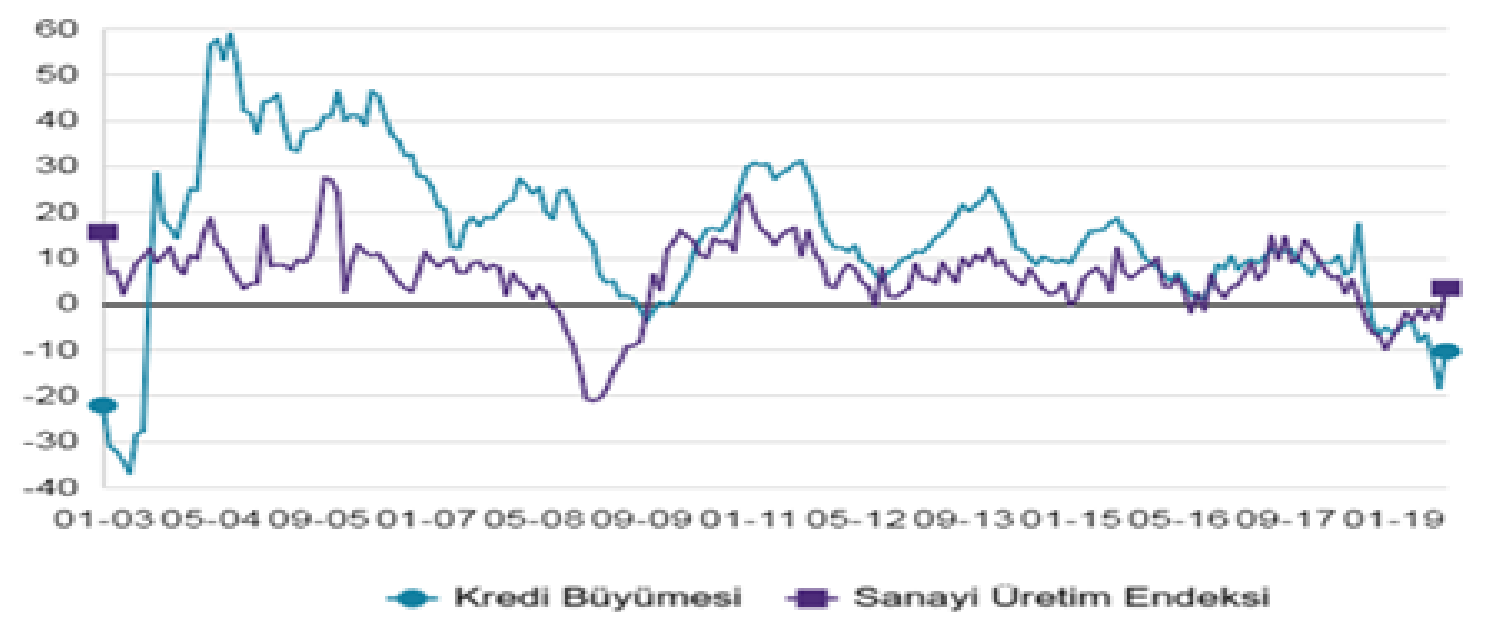

Şekil 1. Türkiye'de kredi büyümesi (\%) ile sanayi üretim endeksi (SÜE) arasındaki ilişki

Kaynak: TÜİK, BDDK'dan aktaran BBC News (Erişim Tarihi: 03.12.2019)

Şekil 2'de Türkiye'de faaliyet gösteren KSB ve ÖSB'lerin kredi hacminin mevduat bankalarının toplam kredi hacmine oranının yıllar itibariyle seyri verilmiştir. Küresel bir dış şok olarak da kabul edebileceğimiz 2008 Küresel Finansal Krizinde dahi bankaların kredi 
verme davranışında bir asimetri gözlenmezken; 2018 Ağustos ayında yaşanan kur şokundan sonra ortaya çıkan asimetri dikkat çekicidir. Diğer taraftan Şekil 1 ile birlikte değerlendirildiğinde, yukarıda dikkat çekilen makasın kapanmasında etkili olan kredi büyümesinin KSB'ler aracılığıyla gerçekleştiği yorumu yapılabilir.

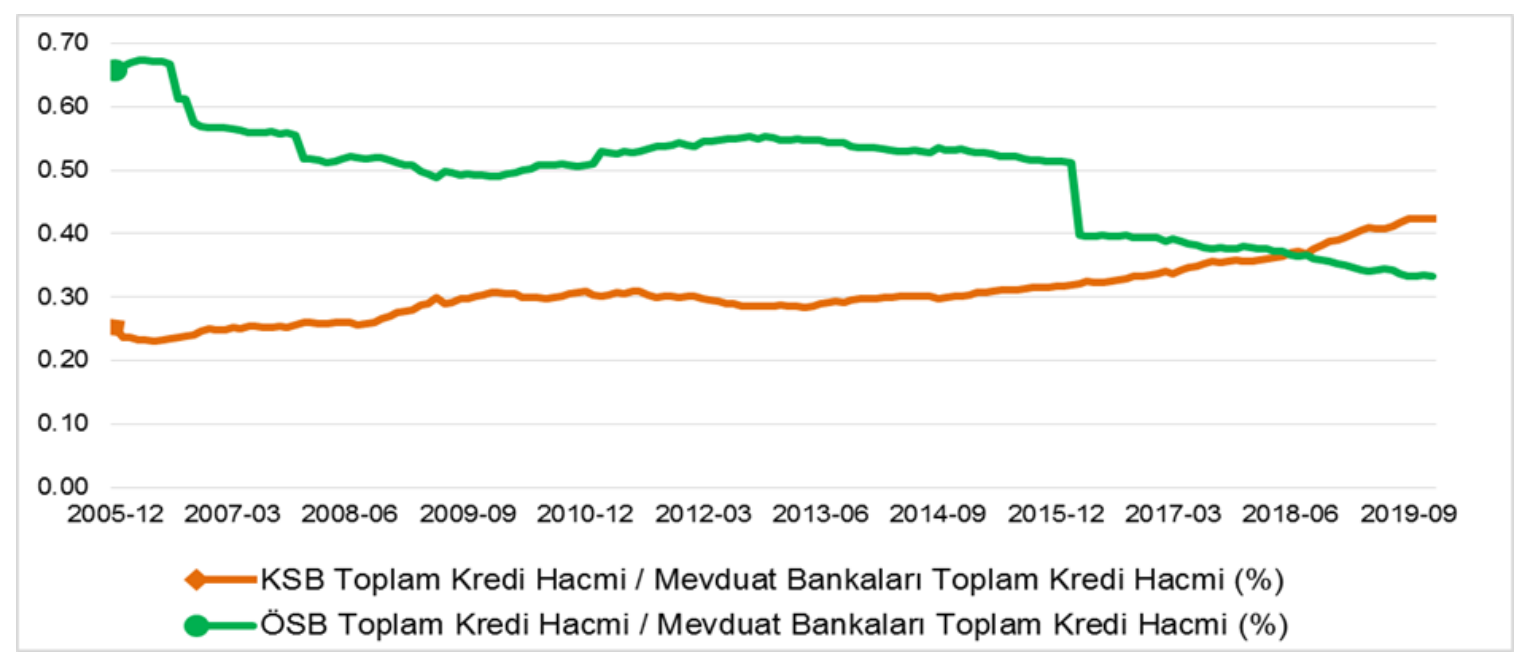

Şekil 2. KSB ve ÖSB'lerde kredi hacmi/toplam kredi hacmi (\%)

Çalışmanın temel motivasyonu KSB ve ÖSB'lerin kredi verme davranışlarındaki bu asimetriyi açıklamaktır. Buna göre çalışmada şu soruların cevapları araştırılmıştır: Birincisi, KSB ve ÖSB'lerin kredi verme davranışlarındaki asimetri bu bankaların takipteki kredilerinden mi yoksa makroekonomik faktörlerden mi kaynaklanmaktadır? İkincisi, eğer sadece makroekonomik faktörler bu asimetriyi açıklıyorsa her iki grup için de ortak mıdır?

Çalışmada 2005 Aralık - 2019 Eylül döneminde ÖSB ve KSB'lerin takibe dönüşüm oranları ile enflasyon, işsizlik ve tüketici güven endeksi makroekonomik göstergelerinin ilgili banka gruplarının kredi hacmine etkileri araştırılmıştır. İki ayrı modelle yapılan çalışmada Gecikmesi Dağıtılmış Otoregresif (Autoregressive Distributed Lag) ARDL Modeli sınır testi yaklaşımı kullanılmıştır. Ampirik analizden elde edilen sonuçlara göre, KSB'lerin kredi hacmi sadece takibe dönüşüm oranından etkilenirken; ÖSB'lerin kredi hacmi takibe dönüşüm oranı, döviz kuru ve tüketici güven endeksinden etkilenmektedir.

Çalışmanın bundan sonraki planlaması şu şekildedir: ikinci bölümde literatür incelemesi, üçüncü bölümde veri setinin tanımlanarak, metodoloji ve ampirik uygulama verilmiştir. Sonuç bölümünde ise uygulama sonuçları yorumlanarak genel değerlendirme yapılmıştır. 


\section{Kurt Cihangir, Ç.}

\section{LITERATÜR TARAMASI}

Bankaların kredi verme davranışlarını etkileyen faktörler literatüre uygun biçimde kredi hacmi ile makroekonomik göstergeler arasındaki ilişkiyi araştıran çalışmalar, kredi hacmi ile takipteki krediler arasındaki ilişkiyi araştıran çalışmalar ve mülkiyet yapısını esas alarak yapılan çalışmalar olarak sınıflandırılmıştır.

Bankaların kredi hacmi ile makroekonomik göstergeler arasındaki ilişkiyi araştıran çalışmalar:

Quagliariello (2009) İtalyan bankalarının makroekonomik belirsizliklerin olduğu durumlarda krediler ile diğer varlık unsurlarının dağılımına ilişkin kararlarını 1990-2005 çeyrek dönemlik verilerle incelemiştir. Buna göre, makroekonomik belirsizliğin arttı̆̆1 dönemlerde geri ödenmeyen kredilerin payı artmakta ve buna bağlı olarak da bankaların varlıklarında kredilerin payı azalmaktadır. Benzer bir çalışma da Baum vd. (2005) tarafından ABD'de faaliyet gösteren tüm bankaların 1979-2003 çeyrek dönemlik ve yıllık verileri kullanılarak yapılmıştır. Çalışma sonucunda, belirsizliğin nispeten düşük olduğu dönemlerde bankaların kredi verme konusunda daha gevşek davrandıkları; belirsizliğin yüksek olduğu dönemlerde ise kredi kullandırma konusunda daha katı davrandıkları sonucuna ulaşmışlardır. Olszak vd. (2018), aralarında Türkiye'nin de olduğu 65 ülkenin 2000-2011 döneminde uyguladıkları borçlu kısıtlamaları, büyük kredi kısıtlamaları, borç-gelir oranı kısıtlamaları gibi makro-ihtiyati politika araçlarının kredi zarar karşılıklarının döngüselliğini azalttığını tespit etmişlerdir. Jorda vd. (2013) çalışmalarında 14 gelişmiş ülkenin 1870-2008 döneminde yaşadıkları krizler sonrasındaki resesyonlar ile iş döngüsünden kaynaklanan resesyonların maliyetlerini incelemişlerdir. Çalışmada, finansal kriz öncesindeki dönemde kredi hacmindeki artışın, kriz sonrası dönemde düşük yatırım, nispeten düşük ekonomik büyüme ve kredi hacminde azalma olarak ortaya çıktığı ve dolayısıyla finansal kriz sonrasındaki resesyonların çok daha maliyetli ve etkili olduğu sonuçlarına ulaşılmıştır.

\section{Bankaların kredi hacmi ile takipteki kredileri arasındaki ilişkiyi araştıran çalışmalar:}

Cucinelli (2015) 2007-2013 döneminde 488 adet İtalyan bankasının kriz dönemlerinde kredi risklerinde bir artış olup olmadığını ve kredi verme davranışlarını araştırmıştır. Buna göre, Cucinelli'nin kredi riskini ölçme amacıyla kullandığı takipteki krediler ve kredi risk karşılığ1 oranının geçmiş kredilere ait değerleri cari dönemde kredi verme davranışını etkilemektedir. Sonuç olarak, artan kredi riski bankanın kredi hacminin azalmasına neden olmaktadır. 
Vithessonthi (2016), Japonya'da1993-2013 döneminde faaliyet gösteren 82 ticari bankanın kredi hacmi ile takipteki kredileri arasındaki ilişkiyi panel regresyon yöntemi ile incelemiştir. Çalışmada, banka kredi hacmindeki artışın, 2007 küresel mali krizinin başlamasından önce takipteki kredilerle pozitif yönde ilişkili iken, krizden sonra takipteki kredilerle negatif yönde ilişkili olduğunu tespit etmiştir. Ayrıca, büyük bankaların kredi hacimlerindeki artışın takipteki kredileri artırmakla birlikte bunun bankanın karlılığını artırmadığını belirtmiştir. Us (2016) çalışmasında kriz öncesi ve sonrası dönem olarak ikiye ayırdığı 2002Ç4-2015Ç4 döneminde makroekonomik ve bankalara ilişkin göstergelerin takipteki krediler üzerindeki etkisini araştırmıştır. Çalışmada, gerek kriz öncesi (2002Ç4-2008Ç3) gerekse kriz sonrası (2008Ç42015Ç4) dönemde banka kredi hacmi ile enflasyon ve döviz kurunun takipteki alacakları etkileyen ortak değişkenler olduğu sonucuna ulaşmıştır. Kriz öncesi dönemde bankaya ilişkin birçok gösterge etkiliyken; kriz sonrası dönemde sadece kredi hacmindeki azalmanın takipteki kredileri etkilediğini belirtmiştir.

Bankaların mülkiyet yapısına göre kredi verme davranışlarını araştıran çalışmalar:

$\mathrm{Bu}$ konuda yapılan uluslararası çalışmaların genellikle bankaların finansal kriz ve/veya istikrarsılık dönemlerindeki davranışlarını açıklamaya yönelik olduğu görülmektedir. Türkiye bankacılık sektörü için yapılan çalışmaların da etkinlik analizi ve takipteki kredilerle kredi davranışı ilişkisinin araştırılmasına yönelik olduğu görülmektedir.

Micco ve Panizza (2006) kamu ve özel sermayeli bankaların kredi verme davranışlarını konjonktürel dalgalanmalar açısından karşılaştırmışlardır. Çalışmalarında KSB'lerin ÖSB'lere göre makroekonomik şoklara daha az duyarlı oldukları sonucuna ulaşmışlardır. Konjonktürel dalgalanma dönemlerinde bankaların kredi verme ve fiyatlama davranışını araştıran Ruckes (2004), ekonomik görünümün iyileşmesinin kredi riskini azalttığını ve bankaların da kredi verme standartlarında esneklik yaparak nispeten daha riskli borçlulara kredi kullandırdıklarını; ekonomik görünümün kötüleşmesi durumunda ise kredi riskinin arttığını ve kredi verme standartlarının katı bir biçimde uygulandığını belirtmiştir. Ruckes ayrıca, mevduat sigortasının da kredi standartlarının değişkenlik göstermesinde etkili olabileceğini belirtmiştir.

Cull ve Peria'ya (2013) göre bankanın mülkiyet yapısı kredi hacmini etkilemektedir. Başka ampirik çalışmalarla da desteklenen bu duruma göre, kriz dönemlerinde ve sonrasında kamu bankaları, özel bankalara oranla kredi verme konusunda daha isteklidirler (Brei ve Schclarek 2013; Cull ve Peria, 2013; Coleman ve Feler, 2015, Yeyati vd., 2007; Bertay vd., 2015). Brei ve Schclarek (2013), 1994-2009 döneminde 50 ülkeden 764 bankanın verileriyle 
Kurt Cihangir, Ç.

yaptıkları çalışmalarında finansal krizlerde ÖSB'ler ve KSB'lerin kredi verme davranışlarını incelemişlerdir. Elde ettikleri bulgulara göre, kriz zamanlarında normal zamanlara göre KSB'lerin kredi hacmi artarken, ÖSB'lerin kredi hacimleri azalmaktadır. Dolayısıyla hükümetler, doğrudan devlete ait bankalar aracılığıyla bankacılık sistemlerinde aktif bir karşıdöngüsel rol oynamaktadırlar. Bertay vd. (2015) de 1999-2010 döneminde 111 ülkeden seçtikleri 1633 ÖSB ve KSB'lerin konjonktürel dalgalanmalardaki kredi hacimlerini araştırmışlardır. Buna göre KSB'ların kredi verme davranışları ÖSB'lerden daha az konjonktüre uygundur. Ayrıca, finansal istikrarsızlık ve ekonomik resesyon dönemlerinde KSB'lerin kredi hacimlerini ÖSB'lere göre daha fazla genişlettiklerini tespit etmişlerdir.

Iannotta vd. (2007) 1999-2004 döneminde 15 Avrupa ülkesinden seçtikleri 181 büyük bankanın mülkiyet yapıları ile karlılık ve maliyet etkinlikleri arasındaki ilişkiyi araştırmışlardır. Çalışmada, kamu sermayeli bankaların özel sermayeli bankalara göre daha düşük karlılık düzeyine sahip oldukları sonucuna ulaşmışlardır. Ay Yalçınkaya ve Kök (2013) çalışmalarında 2005-2013 döneminde Türkiye'de faaliyet gösteren kamu - özel ve yabancı sermayeli bankalar için ölçek yapılarına göre gruplandırarak maliyet etkinlik analizi yapmışlardır. Çalışmalarının sonucunda, ÖSB'lerin KSB'lerden daha maliyet etkin çalıştıklarını tespit etmişlerdir.

Kamu ve özel sermayeli 13 bankanın takipteki kredilerinin, kredi verme davranışına etkisini araştıran Kaya vd. (2016) 2006 Ç4-2014 Ç3 dönemini inceledikleri çalışmalarında dinamik panel regresyon analizini uygulamışlardır. Buna göre takipteki kredilerin toplam krediler üzerindeki etkisi negatif yönlüdür.

\section{VERI SETİ VE AMPÍRIKK UYGULAMA}

\subsection{Veri Seti ve Yöntem}

Kamu ve özel sermayeli bankaların kredi verme davranışlarının araştıııldığı çalışmada kullanılan değişkenler aşağıdadır:

ksbkredi $_{\mathrm{t}}=\mathrm{f}\left(\mathrm{ksbkars}_{\mathrm{t}}, \mathrm{rdk}_{\mathrm{t}}, \operatorname{tge}_{\mathrm{t}}\right.$, tufe $_{\mathrm{t}}$, issizlik $\left._{\mathrm{t}}, u\right)$

osbkredi $\mathrm{t}_{\mathrm{t}}=\mathrm{f}\left(\right.$ osbkars $_{\mathrm{t}}$, rdk $_{\mathrm{t}}$, tge $_{\mathrm{t}}$, tufe $_{\mathrm{t}}$, issizlik $\left._{\mathrm{t}}, u\right)$

Burada, ksbkredit KSB'lerin kredi hacmini, ksbkarst KSB'ların takipteki kredilerinin toplam kredilere oranını, osbkredi $\mathrm{i}_{\mathrm{t}}$ OSB'ların kredi hacmini, osbkars $\mathrm{t}_{\mathrm{t}}$ OSB'ların takipteki kredilerinin toplam kredilere oranını, $\mathrm{rdk}_{\mathrm{t}}$ reel döviz kuru endeksini, tge tüketici güven endeksini, tufe $e_{\mathrm{t}}$ enflasyon oranını ve son olarak issizlik $\mathrm{t}_{\mathrm{t}}$ işsizlik oranını, $u$ ise hata terimini ifade etmektedir. Belirlenen değişkenler için ortak en geniş dönem olan 2005 Aralık-2019 Eylül 
döneminin incelendiği çalışmada tüm veriler Türkiye Cumhuriyet Merkez Bankası'nın (TCMB) Elektronik Veri Dağıtım Sisteminden (EVDS) elde edilmiştir. Buna göre çalışmada kullanılan değişkenler Tablo 1'de verilmiştir.

Tablo 1. Analizde kullanılan değişkenler

\begin{tabular}{|l|l|}
\hline Değişken & \multicolumn{1}{|c|}{ Açıklama } \\
\hline ksbkredi & Kamu Sermayeli Bankaların (KSB) Kredi Hacmi (Milyar TL) \\
\hline osbkredi & Özel Sermayeli Bankaların (ÖSB) Kredi Hacmi (Milyar TL) \\
\hline ksbkars & KSB’ler için Tahsil İmkanı Sınırlı ve Tahsili Şüpheli Krediler / Toplam Krediler (\%) \\
\hline osbkars & ÖSB’ler için Tahsil İmkanı Sınırlı ve Tahsili Şüpheli Krediler / Toplam Krediler (\%) \\
\hline rdk & Reel Efektif Döviz Kuru \\
\hline tge & Tüketici Güven Endeksi \\
\hline tufe & Enflasyon (2003=100) Tüketici Fiyatları Endeksi \\
\hline issiz & İşizlik (\%) \\
\hline
\end{tabular}

Zaman serisi modellerinde ortaya çıkabilecek heterostekasity problemini ortadan kaldırmak veya etkisini azaltmak için para birimi ile (Milyar TL) ifade edilen KSB ve OSB kredi hacmi değişkenlerinin logaritmik değerleri alınmıştır. Buna göre ekonometrik analizde kullanılan modeller aşağıdadır:

$$
\begin{aligned}
& \operatorname{In}(\text { ksbkredi })_{\mathrm{t}}=\alpha_{0}+\alpha_{1} \text { ksbkars }_{\mathrm{t}}+\alpha_{2} \text { rdk }_{\mathrm{t}}+\alpha_{3} \text { tge }_{\mathrm{t}}+\alpha_{4} \text { tufe }_{\mathrm{t}}+\alpha_{5} \text { issiz }_{\mathrm{t}}+u_{\mathrm{t}} \\
& \operatorname{In}(\text { osbkredi })_{\mathrm{t}}=\alpha_{6}+\alpha_{7} \text { osbkars } \mathrm{t}+\alpha_{8} \text { rdk }_{\mathrm{t}}+\alpha_{9} \text { tge }_{\mathrm{t}}+\alpha_{10} \text { tufe }_{\mathrm{t}}+\alpha_{11} \text { issiz }_{\mathrm{t}}+u_{\mathrm{t}}
\end{aligned}
$$

Burada, tahmin edilecek parametre değerleri olan $\alpha_{1}, \alpha_{2}, \alpha_{3}, \alpha_{4}$ ve $\alpha_{5}$ değerleri kredi_ksb ile kars_ksb, rdk, tge, tüfe ve issiz değişkenleri arasındaki; $\alpha_{7}, \alpha_{8}, \alpha_{9}, \alpha_{10}$ ve $\alpha_{11}$ değerleri ise kredi_osb ile kars_osb, rdk, tge, tufe ve issiz değişkenleri arasındaki uzun dönem esnekliklerini ifade etmektedir. $u$ ile gösterilen stokastik hata teriminin normal gereksinimleri karşıladığ varsayılmıştır.

Çalışmada Gecikmesi Dağıtılmış Otoregresif (Autoregressive Distributed Lag - ARDL) Modeli, diğer bir ifadeyle sınır testi yaklaşımı kullanılmıştır. Pesaran ve Shin (1999)'in çalışmaları ile ortaya çıkan ve Pesaran vd. (2001) çalışmaları ile geliştirilen bu model, farklı durağanlık düzeyine sahip değişkenlerin birlikte analiz edilmesini sağlamaktadır. Böylece değişkenler I(0) veya I(1) oldukları bilgisine ihtiyaç duyulmadan analize dahil edilebilir (Pesaran vd., 2001: 290). Diğer taraftan ARDL Modelinde kısıtsız hata düzeltme modeli (unrestricted error correction model) kullanıldığından, model eşbütünleşme testine göre daha iyi istatistiksel bilgiler içermektedir (Narayan ve Narayan, 2005: 429). 
ARDL sınır testi yaklaşımında ilk olarak değişkenler arasındaki uzun dönem ilişki; yani eşbütünleşme ilişkisi, araştırılmaktadır. Buna göre, uzun dönem ilişkinin tespit edilmesi durumunda uzun ve kısa dönem esneklikleri araştırılır. Bu çalışma için uyarlanan ARDL modelleri aşağıdadır:

$$
\begin{gathered}
\text { In (ksbkredi })_{t}=\beta_{0}+\sum_{i=1}^{m} \alpha_{1 i} \Delta \text { In }(\text { ksbkredi })_{t-i}+\sum_{i=0}^{m} \alpha_{2 i} \Delta\left(\text { ksbkars }_{t-i}+\right. \\
\sum_{i=0}^{m} \alpha_{3 i} \Delta(\text { rdk })_{t-i}+\sum_{i=0}^{m} \alpha_{4 i} \Delta(\text { tge })_{t-i}+\sum_{i=0}^{m} \alpha_{5 i} \Delta(\text { tufe })_{t-i}+\sum_{i=0}^{m} \alpha_{6 i}(\text { issiz })_{t-i}+ \\
\theta_{1} \operatorname{In}(\text { ksbkredi })_{t-1}+\theta_{2}(\text { ksbkars })_{t-1}+\theta_{3}(\text { rdk })_{t-1}+\theta_{4}(\text { tge })_{t-1}+\theta_{5}(\text { tufe })_{t-1}+ \\
\theta_{6}(\text { issiz })_{t-1}+\varepsilon_{t} \\
\Delta \text { In }(\text { osbkredi })_{t}=\beta_{1}+\sum_{i=1}^{m} \alpha_{7 i} \Delta \text { In }(\text { osbkredi })_{t-i}+\sum_{i=0}^{m} \alpha_{8 i} \Delta(\text { osbkars })_{t-i}+ \\
\sum_{i=0}^{m} \alpha_{9 i} \Delta(\text { rdk })_{t-i}+\sum_{i=0}^{m} \alpha_{10 i} \Delta(\text { tge })_{t-i}+\sum_{i=0}^{m} \alpha_{11 i} \Delta(\text { tufe })_{t-i}+ \\
\sum_{i=0}^{m} \alpha_{12 i}(\text { issiz })_{t-i}+\theta_{7} \operatorname{In}(\text { osbkredi })_{t-1}+ \\
\theta_{8}(\text { osbkars })_{t-1}+\theta_{9}(r d k)_{t-1}+\theta_{10}(\text { tge })_{t-1}+\theta_{11}(\text { tufe })_{t-1}+\theta_{12}(\text { issiz })_{t-1}+\varepsilon_{t}
\end{gathered}
$$

Burada, $\Delta$ ilgili değişkenin birinci farkını; m, optimal gecikme uzunluğunu; $\alpha_{1 i}, \ldots, \alpha_{12 i}$ hata düzeltme katsayılarını; eşitliğin ikinci kısmındaki $\theta_{1}, \ldots, \theta_{12}$ modelin uzun dönem çarpanlarını; ve $\varepsilon_{t}$ beyaz gürültü (white noise) terimini ifade etmektedir.

Optimal gecikme uzunluğunun belirlenmesinde Akaike (AIC), Schwarz (SBC), Hannan-Quin (HQ) bilgi kriterleri kullanılmaktadır. Buna göre, ilgili bilgi kriterlerinin en küçük değeri aldığı gecikme uzunluğu, modelin optimal gecikme uzunluğu olarak kabul edilmektedir. Sonraki aşamada, optimal gecikme uzunluğuna göre OLS tekniği ile kurulan modelde otokorelasyon ve değişen varyans sorunlarının olup olmadığ 1 test edilmektedir. Belirlenen denklem sisteminin çalıştırılmasıyla $\mathrm{H} 0=\theta_{1}=\theta_{2}=\ldots=\theta_{12}=0$ şeklindeki temel hipotezin geçerliliğine $\mathrm{F}$ istatistik değerine göre karar verilir. Buna göre, $\mathrm{F}$ istatistik değeri için hesaplanan kritik değer \%1, \%2,5, \%5 ve \%10 istatistiksel anlamlılık seviyelerine ait alt ve üst sınır değerleri ile karşılaştırılır (Pesaran ve Pesaran, 2009). F değeri, belirlenen kritik değerlerin üst sınır değerinden büyükse değişkenler arasında uzun dönemde ilişki olduğu (H0 hipotezi reddedilir), alt sınır değerinden küçükse ilişki olmadığı (H0 hipotezi kabul edilir) kararına varılır. F kritik değerinin alt ve üst sınır değerleri arasında olması durumunda ise uzun dönem ilişki hakkında yorum yapılamaz.

Yukarıdaki (3) ve (4) nolu denklem sistemlerinin çalıştırılması sonucunda değişkenler arasında uzun dönem ilişki olduğunun belirlenmesi durumunda uzun ve kısa dönem katsayıları hesaplanmaktadır. Kısa dönem ilişkinin tahmin edilmesinde uzun dönem ilişkisinde elde edilen 
hata teriminin bir dönem gecikmeli değeri kullanılmaktadır. İlgili (5) ve (6) nolu denklemler aşağıdadır:

$$
\begin{aligned}
& \Delta \text { In }(k s b k r e d i)_{t}=\beta_{0}+\sum_{i=1}^{m} \alpha_{1 i} \Delta \text { In }(k s b k r e d i)_{t-i}+\sum_{i=0}^{m} \alpha_{2 i} \Delta(k s b k a r s)_{t-i}+ \\
& \sum_{i=0}^{m} \alpha_{3 i} \Delta(r d k)_{t-i}+\sum_{i=0}^{m} \alpha_{4 i} \Delta(\text { tge })_{t-i}+\sum_{i=0}^{m} \alpha_{5 i} \Delta(t u f e)_{t-i}+\sum_{i=0}^{m} \alpha_{6 i}(i s s i z)_{t-i}+ \\
& \psi E C T_{t-1}+\varepsilon_{t} \\
& \Delta \operatorname{In}(\text { osbkredi })_{t}=\beta_{0}+\sum_{i=1}^{m} \alpha_{1 i} \Delta \operatorname{In}(\text { osbkredi })_{t-i}+\sum_{i=0}^{m} \alpha_{2 i} \Delta(\text { osbkars })_{t-i}+ \\
& \sum_{i=0}^{m} \alpha_{3 i} \Delta(r d k)_{t-i}+\sum_{i=0}^{m} \alpha_{4 i} \Delta(\text { tge })_{t-i}+\sum_{i=0}^{m} \alpha_{5 i} \Delta(\text { tufe })_{t-i}+\sum_{i=0}^{m} \alpha_{6 i}(i s s i z)_{t-i}+ \\
& \psi E C T_{t-1}+\varepsilon_{t}
\end{aligned}
$$

Burada uzun dönem eşitliğinden elde edilen $\alpha_{1 i}, \ldots, \alpha_{12 i}$ değerleri k1sa dönem katsayılarını göstermektedir. $\psi$ hata teriminin gecikmeli değerini gösterir ve $H T K=$ $\operatorname{In}\left(\right.$ ksbkredi $_{t}-\left(\theta_{1}\right.$ Inksbkars $_{t}+\theta_{2} r d k+\theta_{3}$ tge $+\theta_{4}$ tufe $+\theta_{5}$ issiz $) \quad$ olarak ifade edilebilir. Buna göre, hata düzeltme katsayısının (HDT - Error Correction Term) negatif değerde ve istatistiksel olarak anlamlı olması beklenir. Bu koşulu sağlayan HDT kısa dönemde oluşan dengesizliklerin ne kadar sürede dengeye geleceğini ve uzun dönem dengenin devam edeceğini göstermektedir.

\subsection{Ampirik Uygulama}

2005 Aralık-2019 Eylül dönemine ait aylık frekansta verilerin kullanıldığı çalışmada bu değişkenlere ait tanımlayıcı istatistik değerleri Tablo 2'de verilmiştir. Buna göre, lksbkredi ve losbkredi bağımlı değişkenlerini açıklayıcı değişkenler arasında en düşük standart sapma ksbkars ve osbkars değişkenlerine aittir. Kredi hacmi açısından en küçük ve en büyük değerler karşılaştırıldığında KSB'lerın OSB'lere göre daha geniş aralığa sahip olduğu görülmektedir. Diğer taraftan iktisadi birimlerin ekonomiye duydukları güveni ifade eden tge değişkenine ait en büyük değerin 89.0438 olması, normal değer kabul edilen 100’ün altında kaldığı için, beklentilerin iyimser olduğunu söylemenin güç olduğunu göstermektedir. 
Kurt Cihangir, Ç.

Tablo 2. Değişkenlere ait tanımlayıcı istatistik değerleri

\begin{tabular}{|l|c|c|c|c|c|c|}
\hline \multicolumn{1}{|c|}{ Değişken } & Gözlem & Ortalama & St. Sapma & Ortanca & En Küçük & En Büyük \\
\hline lksbkredi & 166 & 5.2219 & 0.9844 & 5.2115 & 3.3558 & 6.7692 \\
\hline losbkredi & 166 & 5.7035 & 0.7345 & 5.8701 & 4.3878 & 6.6849 \\
\hline ksbkars & 166 & 3.3942 & 1.3741 & 2.6419 & 2.0826 & 8.3401 \\
\hline osbkars & 166 & 3.4080 & 1.3235 & 3.1025 & 1.7279 & 6.5885 \\
\hline rdk & 166 & 104.5167 & 14.335 & 107.0050 & 62.5100 & 127.7200 \\
\hline tge & 166 & 71.8910 & 7.6550 & 72.4867 & 55.1000 & 89.0438 \\
\hline tufe & 166 & 228.6515 & 80.0053 & 212.0200 & 122.6500 & 427.0400 \\
\hline issiz & 166 & 10.3626 & 1.6855 & 10.2000 & 7.3000 & 14.8000 \\
\hline $\begin{array}{l}\text { ksbkredi ve osbkredi değişkenlerinin doğal logaritmaları alınmıştır. Tüm değerler Eviews } 10 \text { programı } \\
\text { kullanılarak hesaplanmıştır. }\end{array}$
\end{tabular}

Zaman serilerinin sabit olmaması nedeniyle bu serilerle kurulan modeller sahte regresyon veya doğru olmayan sonuçlara neden olabilir (Maddala, 2001). Bu nedenle değişkenlerin durağanlıklarının sınanması gerekmektedir. Bu çalışmada durağanlık sınaması Genişletilmiş Dickey-Fuller (ADF, 1981) ve Phillips ve Perron (PP, 1988) testleri ile yapılmıştır ve ilgili sonuçlar Tablo 2'de verilmiştir. Tablo 3'de görüldügü üzere issiz değişkeni dışındaki değişkenlerin tümü birinci farkı alındığında I(1) durağan hale gelmiştir. issiz değişkeni ise düzeyde I(0) durağandır. Buna göre çalışmada $\mathrm{I}(1)$ ve $\mathrm{I}(0)$ değişkenlerinin birlikte kullanılmasını destekleyen ARDL modelinin kullanılması uygundur.

Tablo 3. Durağanlık için birim kök testleri

\begin{tabular}{|c|c|c|c|c|c|}
\hline Değişken & & $\mathrm{ADF}_{c}$ & $\mathbf{A D F}_{c+t}$ & $\mathbf{P P}_{c}$ & $\mathbf{P} \mathbf{P}_{c+t}$ \\
\hline \multirow[t]{2}{*}{ losbkredi } & Düzey & -1.8236 & -1.6455 & -1.7160 & -1.8617 \\
\hline & Birinci Fark & $-11.9785^{\text {**** }}$ & $-12.3472^{* * *}$ & $-11.9891^{\text {**** }}$ & $-12.3472^{* * *}$ \\
\hline \multirow[t]{2}{*}{ losbkredi } & Düzey & -2.0325 & -0.1019 & -1.8151 & -0.4581 \\
\hline & Birinci Fark & $-11.1428^{* * *}$ & $-11.3808^{* * *}$ & $-11.3038^{* * *}$ & $-11.4947^{* * *}$ \\
\hline \multirow[t]{2}{*}{ ksbkars } & Düzey & -1.9416 & -2.1676 & $-4.7526^{* * *}$ & -3.0329 \\
\hline & Birinci Fark & $-3.4928^{* * *}$ & $-3.3580^{*}$ & $-11.7107^{* * *}$ & $-12.3605^{* * *}$ \\
\hline \multirow[t]{2}{*}{ osbkars } & Düzey & -1.2461 & -0.8124 & -1.0488 & -0.3554 \\
\hline & Birinci Fark & $-3.94120^{* * *}$ & $-4.1841^{* * *}$ & $-9.7919^{* * *}$ & $-10.134^{* * *}$ \\
\hline \multirow[t]{2}{*}{$\mathrm{rdk}$} & Düzey & -0.9119 & -2.5299 & -0.9389 & -2.8194 \\
\hline & Birinci Fark & $-10.2259^{* * *}$ & $-10.2138^{* * *}$ & $-9.5949^{* * *}$ & $-9.5677^{* * *}$ \\
\hline \multirow[t]{2}{*}{ tge } & Düzey & -2.4344 & -2.9421 & -2.2548 & -2.8769 \\
\hline & Birinci Fark & $-11.7583^{* * *}$ & $-11.7219^{* * * *}$ & $-12.2985^{* * * *}$ & $-12.2440^{* * *}$ \\
\hline \multirow[t]{2}{*}{ tufe } & Düzey & 4.5720 & 2.3538 & 5.1117 & 1.9892 \\
\hline & Birinci Fark & $-3.9328^{* * *}$ & $-6.9548^{* * *}$ & $-8.3816^{* * *}$ & $-9.1344^{* * * *}$ \\
\hline \multirow[t]{2}{*}{ issiz } & Düzey & $-3.1078^{* *}$ & $-3.3563^{*}$ & -1.9911 & -2.3292 \\
\hline & Birinci Fark & $-3.2298^{* *}$ & -3.2632 & $-5.7312^{* * *}$ & $-7.2514^{* * *}$ \\
\hline
\end{tabular}


Yöntem bölümünde (3.1.) anlatılan sürece göre aşamalar şu şekildedir: öncelikle optimal gecikme uzunluğu belirlenmiştir, ikinci aşamada $\mathrm{F}$ istatistiğinin kritik değerlerle karşılaştırılması yapılmıştır ve son aşamada ise uzun ve kısa dönem ilişkilerin araştırılması yapılmıştır.

Optimal gecikme uzunluğunun belirlenmesinde Akaike (Akaike Information Criterion AIC), Schwarz (Schwarz Information Criterion SIC) ve HannanQuinn (HannanQuinn Information Criterion HQC) bilgi kriteleri kullanılmıştır. Gecikme sayısı Pesaran ve Pesaran (1997)'nin aylık veriler için önerdiği 12 olarak belirlenmiştir. Normal dağılım varsayımında her bir gecikmedeki AIC, SIC ve HQC bilgi kriterlerinin değerleri ile Breusch-Godfrey Oto Korelasyon LM Testi, Breusch-Pagan-Godfrey Testi ile yapılan değişen varyans testlerinin değerleri ve F istatistik ve hata düzeltme terimi değerleri (Bknz. Ek. 1) Tablo 4'de ve Tablo 5'de verilmiştir. Tablo 3'de görüldüğü üzere, bilgi kriterlerinin en küçük değeri aldığı ve bu gecikme sayısında otokorelasyon ve değişen varyans sorunları olmadığı için KSB'ler için en uygun gecikme uzunluğu 12 olarak belirlenmiştir. Bu durumda seçilen ARDL modeli (1, 4, 8, $1,6,0)^{\prime}$ dir.

Tablo 4. KSB'ler için optimal gecikme uzunluğunun belirlenmesi

\begin{tabular}{|c|c|c|c|c|c|c|c|c|}
\hline $\begin{array}{c}\text { Gecikme } \\
\text { Uzunluğu }\end{array}$ & Seçilen Model & AIC & SIC & HQC & $\begin{array}{c}\text { Oto } \\
\text { korelasyon }\end{array}$ & $\begin{array}{c}\text { Değișen } \\
\text { Varyans }\end{array}$ & $\begin{array}{c}\text { Sinır } \\
\text { Testi }\end{array}$ & HDT(-1) \\
\hline 1 & $(1,0,1,0,1,1)$ & -5.9032 & -5.7142 & -5.8265 & 0.8185 & 0.1712 & 62.6191 & -1.0169 \\
\hline 2 & $(2,0,1,0,1,1)$ & -5.9472 & -5.7385 & -5.8625 & 0.7209 & 0.1485 & 35.8712 & -0.9289 \\
\hline 3 & $(3,3,1,1,3,0)$ & -5.9521 & -5.6280 & -5.8205 & 0.6831 & 0.3085 & 6.6869 & -0.8469 \\
\hline 4 & $(4,3,1,1,1,0)$ & -5.9650 & -5.6587 & -5.8406 & 0.5525 & 0.2854 & 6.9053 & -0.9080 \\
\hline 5 & $(4,3,1,1,1,0)$ & -5.9650 & -5.6587 & -5.8406 & 0.5525 & 0.2854 & 6.9053 & -0.9080 \\
\hline 6 & $(1,6,1,1,6,0)$ & -5.9750 & -5.5696 & -5.8104 & 0.7616 & 0.1059 & 27.0671 & -1.1320 \\
\hline 7 & $(4,3,1,1,1,0)$ & -5.9650 & -5.6587 & -5.8406 & 0.5525 & 0.2854 & 6.9053 & -0.9080 \\
\hline 8 & $(1,6,8,1,6,0)$ & -5.9882 & -5.4431 & -5.7668 & 0.9801 & 0.2082 & 25.2509 & -1.1326 \\
\hline 9 & $(1,6,8,1,6,0)$ & -5.9882 & -5.4431 & -5.7668 & 0.9801 & 0.2082 & 25.2509 & -1.1326 \\
\hline 10 & $(1,6,8,1,6,0)$ & -5.9882 & -5.4431 & -5.7668 & 0.9801 & 0.2082 & 25.2509 & -1.1326 \\
\hline 11 & $(10,11,1,7,6,11)$ & -6.0156 & -4.9901 & -5.5991 & 0.5876 & 0.1859 & 5.3563 & -1.3159 \\
\hline $\mathbf{1 2}$ & $\mathbf{( 1 , 4 , 8 , 1 , 6 , 0 )}$ & $\mathbf{- 5 . 9 8 2 6}$ & $\mathbf{- 5 . 4 7 6 5}$ & $\mathbf{- 5 . 7 7 7 1}$ & $\mathbf{0 . 9 5 4 2}$ & $\mathbf{0 . 3 9 8 0}$ & $\mathbf{2 5 . 3 6 8 0}$ & $\mathbf{- 1 . 1 2 9 4}$ \\
\hline
\end{tabular}

OSB'ler için kurulan ARDL modelinde gecikme sayısının 4-12 aralığında belirlenmesi durumunda değişen varyans sorunu ortaya çıkmaktadır. İlgili tanı testleri Ek-2'de verilmiştir. Buna göre, bilgi kriterlerinin en küçük değeri aldığı ve tanı testlerinin oto korelasyon ve değişen varyans sorunu içermediği gecikme uzunluğu olan 3 en uygun gecikme uzunluğu olarak belirlenmiştir. Bu duruma göre seçilen ARDL modeli (1, 0, 2, 2, 2, 0) modelidir. 
Kurt Cihangir, Ç.

Tablo 5. OSB'ler için optimal gecikme uzunluğunun belirlenmesi

\begin{tabular}{|c|c|c|c|c|c|c|c|c|}
\hline $\begin{array}{c}\text { Gecikme } \\
\text { Uzunluğu }\end{array}$ & Seçilen Model & AIC & SIC & HQC & $\begin{array}{c}\text { Oto } \\
\text { korelasyon }\end{array}$ & $\begin{array}{c}\text { Değişen } \\
\text { Varyans }\end{array}$ & $\begin{array}{c}\text { Sinır } \\
\text { Testi }\end{array}$ & HDT(-1) \\
\hline 1 & $(1,0,0,1,0,0)$ & -4.3728 & -4.2216 & -4.3114 & 0.8627 & 0.7281 & 37.7854 & -1.0232 \\
\hline 2 & $(1,0,2,2,2,0)$ & -4.3911 & -4.1443 & -4.2909 & 0.9159 & 0.5999 & 34.8251 & -1.0525 \\
\hline $\mathbf{3}$ & $(\mathbf{1 , 0 , 2 , 2 , 2 , 0 )}$ & $\mathbf{- 4 . 3 9 1 1}$ & $\mathbf{- 4 . 1 4 4 3}$ & $\mathbf{- 4 . 2 9 0 9}$ & $\mathbf{0 . 9 1 5 9}$ & $\mathbf{0 . 5 9 9 9}$ & $\mathbf{3 4 . 8 2 5 1}$ & $\mathbf{- 1 . 0 5 2 5}$ \\
\hline 4 & $(1,0,2,4,0,0)$ & -4.4496 & -4.2008 & -4.3486 & 0.9291 & 0.0007 & 34.1292 & -1.0384 \\
\hline 5 & $(1,0,2,4,0,0)$ & -4.4496 & -4.2008 & -4.3486 & 0.9291 & 0.0007 & 34.1292 & -1.0384 \\
\hline 6 & $(1,0,2,4,0,0)$ & -4.4496 & -4.2008 & -4.3486 & 0.9291 & 0.0007 & 34.1292 & -1.0384 \\
\hline 7 & $(1,0,2,4,0,0)$ & -4.4496 & -4.2008 & -4.3486 & 0.9291 & 0.0007 & 34.1292 & -1.0384 \\
\hline 8 & $(1,0,5,4,2,0)$ & -4.4489 & -4.1029 & -4.3084 & 0.9898 & 0.0024 & 35.0113 & -1.0460 \\
\hline 9 & $(1,0,2,4,0,0)$ & -4.4496 & -4.2008 & -4.3486 & 0.9291 & 0.0007 & 34.1292 & -1.0384 \\
\hline 10 & $(3,0,2,4,4,0)$ & -4.4252 & -4.0616 & -4.2775 & 0.7274 & 0.0010 & 13.1890 & -0.9659 \\
\hline 11 & $(1,0,2,4,2,0)$ & -4.4479 & -4.1608 & -4.3313 & 0.9737 & 0.0010 & 34.7336 & -1.0395 \\
\hline 12 & $(1,0,2,4,2,0)$ & -4.4479 & -4.1608 & -4.3313 & 0.9737 & 0.0010 & 34.7336 & -1.0395 \\
\hline
\end{tabular}

Değişkenlerin uzun dönem katsayıları Tablo 6'da ve Tablo 7'de verilmiştir. KSB için oluşturulan Tablo 6'da, ksbkredi bağımlı değişkenini uzun dönemde etkileyen tek değişken \%1 anlamlılık düzeyinde ksbkars'dır. Diğer açıklayıcı değişkenlerin uzun dönemde ksbkredi üzerinde etkilerinin olmadığı belirlenmiştir. Bu sonuçlara göre, kamu sermayeli bankaların verdikleri krediler içinde takipteki kredilerin oranının artması (ksbkars), uzun vadede, kamu sermayeli bankaların kredi hacminin (ksbkredi) düşmesine neden olmaktadır.

Tablo 6. ARDL (1, 4, 8, 1, 6, 0) modelinin uzun dönem katsayıları (KSB)

\begin{tabular}{|l|c|c|c|}
\hline Değişken & Katsayı & Standart Hata & Olasılık \\
\hline dksbkars & -0.0926 & 0.0136 & $0.0000^{* * *}$ \\
\hline drdk & -0.0004 & 0.0009 & 0.6476 \\
\hline dtge & 0.0005 & 0.0005 & 0.2332 \\
\hline dtufe & -0.0004 & 0.0007 & 0.5259 \\
\hline dissiz & 0.0005 & 0.0006 & 0.3273 \\
\hline Sabit Terim & 0.0132 & 0.0059 & 0.0277 \\
\hline \multirow{2}{*}{,$* * * *$ sirasıly $\% 1, \% 5$ ve $\% 10$ düzeyinde istatistiki anlamlılı̆̆ ifade etmektedir } \\
\hline
\end{tabular}

ÖSB için oluşturulan Tablo 7'de, osbkredi bağımlı değişkenini uzun dönemde etkileyen değişkenler, \%1 istatistiksel anlamlılık düzeyinde osbkars, rdk ve tge değişkenleridir. tufe ve issiz değişkenlerinin uzun dönemde osbkredi üzerinde istatistiksel olarak etkilerinin olmadığ belirlenmiştir. Elde edilen sonuçlara göre, özel sektörün verdiği krediler içinde takipteki kredilerin oranının (osbkars) ve reel döviz kurunun (rdk) artması, uzun vadede, özel sektörün 
kredi hacminin (osbkredi) düşmesine neden olmaktadır. Diğer taraftan, tüketici güven endeksindeki (tge) artış, uzun vadede, özel sektör kredi hacminin (osbkredi) artmasına neden olmaktadir.

Tablo 7. ARDL $(1,0,2,2,2,0)$ modelinin uzun dönem katsayıları (OSB)

\begin{tabular}{|c|c|c|c|}
\hline Değişken & Katsayı & Standart Hata & Olasılık \\
\hline dosbkars & -0.0862 & 0.0127 & $0.0000^{* * *}$ \\
\hline drdk & -0.0039 & 0.0012 & $0.0009^{* * *}$ \\
\hline dtge & 0.0041 & 0.0013 & $0.0024^{* * *}$ \\
\hline dtufe & -0.0003 & 0.0011 & 0.7728 \\
\hline dissiz & 0.0000 & 0.0013 & 0.9971 \\
\hline Sabit Terim & 0.0142 & 0.0130 & 0.2769 \\
\hline
\end{tabular}

Uzun dönem eşitliğinden elde edilen kısa dönem katsayıları ve hata düzeltme terimleri Tablo 8'de Tablo 9'da verilmiştir. Tablo 8 incelendiğinde, kısa dönemde ksbkredi değişkeni ksbkars ve rdk değişkenlerinden \%1 anlamlılık düzeyinde etkilenirken tge değişkeninin etkisinin olmadığı belirlenmiştir. Ayrıca tüfe değişkeni düzeyde etkili olmamasına karşın, 4 ve 5 gecikmeli değerlerinin ksbkredi üzerinde etkisi olduğu görülmektedir. Modelin hata düzeltme katsayısı beklendiği gibi, negatif değerde ve istatistiksel olarak anlamlıdır. -1.1294 ifadesi kısa dönemdeki sapmaları göstermektedir. Buna göre 1/HDT oranlanmasıyla kısa dönemdeki sapmaların ne kadar sürede dengeye geldiği hesaplanabilir. 1/1.1294 =0.88 ayda yani bir aydan daha kısa bir zamanda (yaklaşık 26 gün) sapma dengeye gelmektedir. 
Kurt Cihangir, Ç.

Tablo 8. ARDL $(1,4,8,1,6,0)$ modelinin kısa dönem katsayıları (KSB)

\begin{tabular}{|c|c|c|c|}
\hline Değişken & Katsayı & Standart Hata & Olasılık \\
\hline $\mathrm{d}$ (dksbkar) & -0.0990 & 0.0095 & $0.0000^{* * * *}$ \\
\hline $\mathrm{d}(\mathrm{dksbkar}(-1))$ & -0.0110 & 0.0119 & 0.3546 \\
\hline $\mathrm{d}(\mathrm{dksbkar}(-2))$ & -0.0333 & 0.0117 & $0.0050^{* * * *}$ \\
\hline $\mathrm{d}(\mathrm{dksbkar}(-3))$ & -0.0204 & 0.0092 & $0.0279^{* *}$ \\
\hline $\mathrm{d}(\mathrm{drdk})$ & -0.0021 & 0.0003 & $0.0000^{* * *}$ \\
\hline $\mathrm{d}(\operatorname{drdk}(-1))$ & -0.0009 & 0.0004 & $0.0242^{* *}$ \\
\hline $\mathrm{d}(\operatorname{drdk}(-2))$ & -0.0012 & 0.0004 & $0.0059^{* * * *}$ \\
\hline $\mathrm{d}(\operatorname{drdk}(-3))$ & -0.0011 & 0.0004 & $0.0122^{* * *}$ \\
\hline $\mathrm{d}(\operatorname{drdk}(-4))$ & -0.0011 & 0.0004 & $0.0157^{* *}$ \\
\hline $\mathrm{d}(\operatorname{drdk}(-5))$ & -0.0014 & 0.0004 & $0.0013^{* * *}$ \\
\hline $\mathrm{d}(\operatorname{drdk}(-6))$ & -0.0011 & 0.0003 & $0.0027^{* * * *}$ \\
\hline $\mathrm{d}(\operatorname{drdk}(-7))$ & -0.0012 & 0.0003 & 0.0001 \\
\hline $\mathrm{d}(\mathrm{dtge})$ & -0.0003 & 0.0003 & 0.2733 \\
\hline $\mathrm{d}($ dtufe $)$ & 0.0003 & 0.0004 & 0.5201 \\
\hline $\mathrm{d}(\mathrm{dtufe}(-1))$ & 0.0002 & 0.0005 & 0.5912 \\
\hline $\mathrm{d}(\operatorname{dtufe}(-2))$ & -0.0000 & 0.0005 & 0.9937 \\
\hline $\mathrm{d}(\mathrm{dtufe}(-3))$ & -0.0004 & 0.0005 & 0.3847 \\
\hline $\mathrm{d}(\mathrm{dtufe}(-4))$ & -0.0009 & 0.0004 & $0.0420^{* *}$ \\
\hline $\mathrm{d}(\mathrm{dtufe}(-5))$ & -0.0011 & 0.0004 & $0.0083^{* * *}$ \\
\hline HDT(-1)* & -1.1294 & 0.0829 & $0.0000^{* * * *}$ \\
\hline
\end{tabular}

Tablo 9 incelendiğinde rdk değişkeninin hem düzey hem de 1 gecikmeli değeri, tge ve tüfe değişkenlerinin ise 1 gecikmeli değerlerinin osbkredi değişkeninin, kısa dönemde etkilediği belirlenmiştir. Bu modelde de HDT beklendiği gibi negatif değerde ve istatistiksel olarak anlamlıdır. Buna göre HDT’nin -1.0525 olması 1/1.0525 oranlaması ile 0.95 ayda (yaklaşık 28,5 gün) kısa dönemdeki sapmaların dengeye geldiği yorumu yapılabilir.

Tablo 9. ARDL (1, 0, 2, 2, 2, 0) modelinin kısa dönem katsayıları (ÖSB)

\begin{tabular}{|c|c|c|c|}
\hline Değişken & Katsayı & Standart Hata & Olasılık \\
\hline $\mathrm{d}(\mathrm{drdk})$ & -0.0028 & 0.0006 & $0.0000^{* * * *}$ \\
\hline $\mathrm{d}(\operatorname{drdk}(-1))$ & 0.0018 & 0.0006 & $0.0050^{* * *}$ \\
\hline d(dtge) & 0.0004 & 0.0006 & 0.5335 \\
\hline $\mathrm{d}(\operatorname{dtge}(-1))$ & -0.0016 & 0.0006 & $0.0126^{* *}$ \\
\hline $\mathrm{d}($ dtufe $)$ & 0.0002 & 0.0007 & 0.7661 \\
\hline $\mathrm{d}(\operatorname{dtufe}(-1))$ & 0.0019 & 0.0007 & $0.0085^{* * *}$ \\
\hline HDT $(-1)^{*}$ & -1.0525 & 0.0661 & $0.0000^{* * * *}$ \\
\hline
\end{tabular}


En uygun ARDL Modelinin belirlenmesinin ardından uzun dönem katsayılarının sağlamlığını ölçmek için Pesaran ve Pesaran (1997) ve Pesaran ve Shin (1999) çalışmalarında önerilen kümülatif toplam (CUSUM) ve kümülatif kareler toplamı (CUSUMQ) sağlamlık testleri yapılmıştır. İlgili testlerin sonuçları Şekil 3 ve Şekil 4'de verilmiştir.

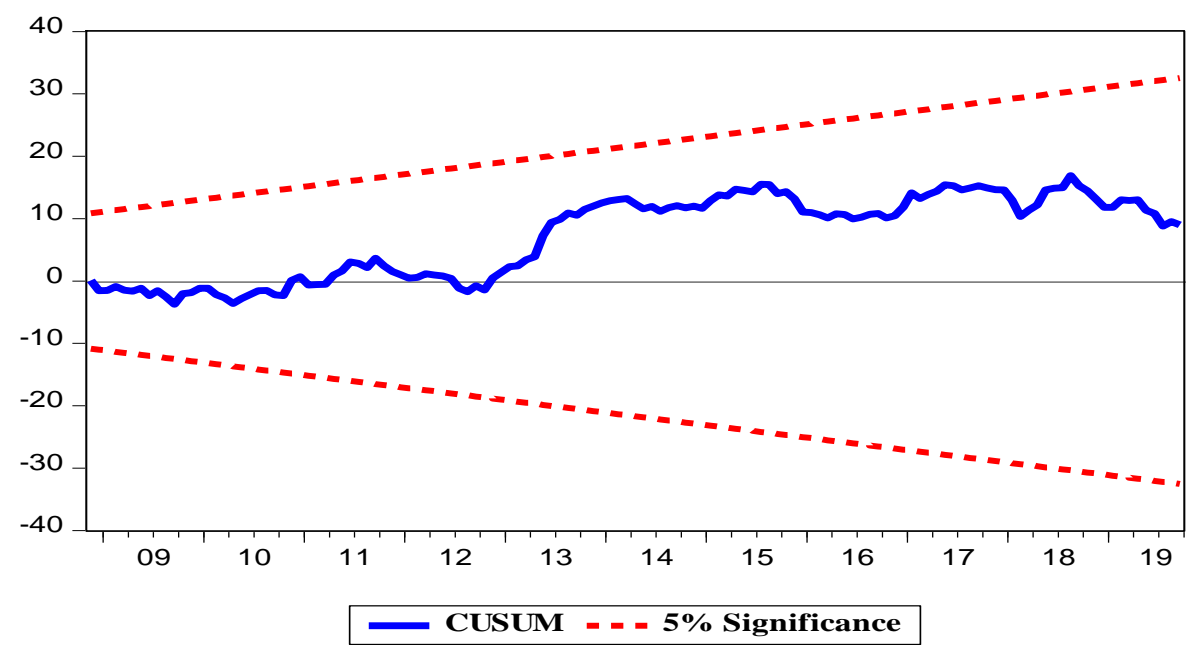

Şekil 3. Kümülatif toplam grafiği (CUSUM) - KSB

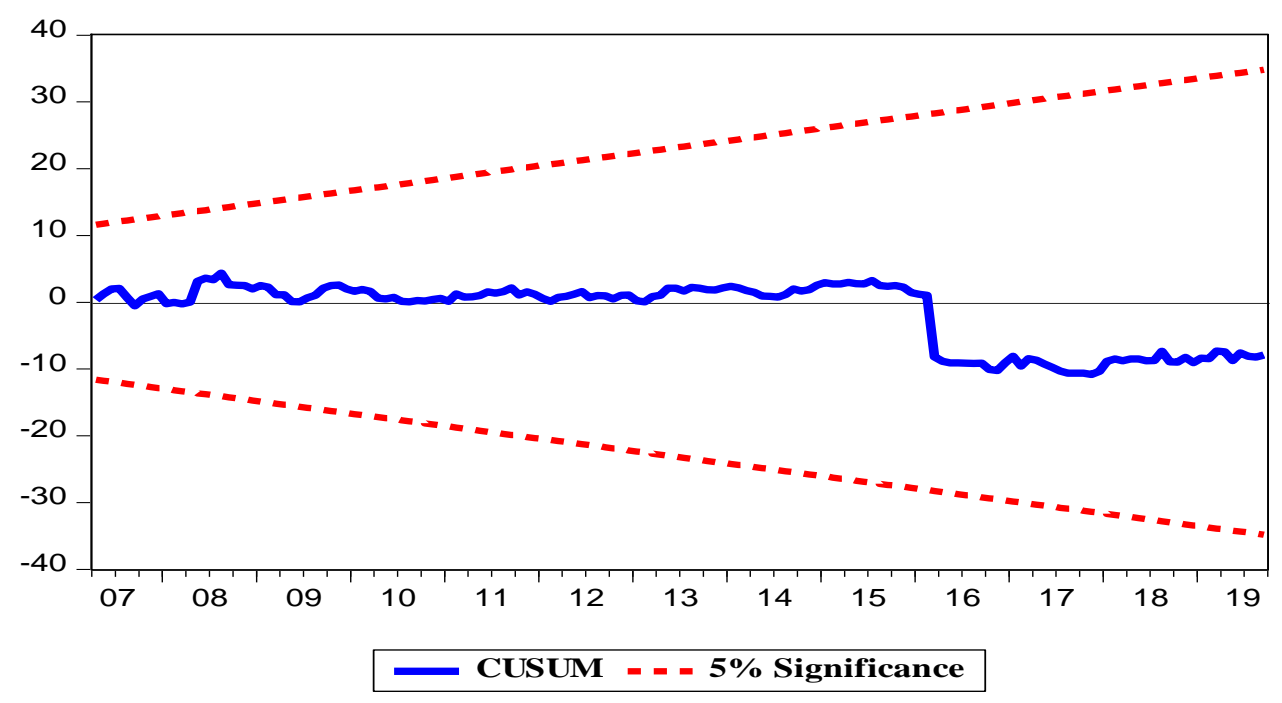

Şekil 4. Kümülatif toplam grafiği (CUSUM) - ÖSB

\section{SONUÇ VE DEĞERLENDİRME}

Türkiye finansal piyasalarında bankacılık sisteminin ağırlıkta olması ekonomik büyümenin banka kredileri yoluyla sağlandığını göstermektedir. Ancak kredi piyasasının doğası gereği asimetrik bilgi içermesi nedeniyle kredilerin her zaman verimli ve nitelikli yatırımların / projelerin finansmanında kullanılması mümkün olmamaktadır. Buna göre dış şoklar, makroekonomik göstergeler, bankaya özgü faktörlerden takipteki krediler ve bankanın mülkiyet yapısı, bankaların kredi verme davranışlarını etkileyen temel faktörlerdir. 
Kurt Cihangir, Ç.

Bu çalışmada Türkiye finansal piyasalarında Ağustos 2018'de yaşanan kur şoku sonrasında kamu sermayeli bankalar (KSB) ve özel sermayeli bankaların (ÖSB) kredi verme davranışlarında gözlenen asimetri dış şoku temsilen döviz kuru, makroekonomik göstergeleri temsilen enflasyon (TÜFE), tüketici güven endeksi (TGE) ve işsizlik oranı, bankaya özgü faktörleri temsilen de ilgili banka grubunun takipteki kredilerinin toplam kredilere oranı, yani takibe dönüşün oranı göstergeleri ile araştırılmıştır. Çalışmada 2008 küresel finansal kriz sırasında KSB ve ÖSB’lerin kredi verme davranışlarıını da gözlemleyebilmek amacıyla 2005 Aralık - 2019 Eylül dönemi verileri kullanılmıştır. Değişkenler arasındaki kısa ve uzun dönem ilişkiyi tahmin etmek için ilişki KSB ve ÖSB’ler için ayrı ayrı kurulan otoregresif gecikmesi dağıtılmış model (ARDL) sınır testi yaklaşımı kullanılmıştır. Yapılan ampirik analizler sonrasında şu bulgulara ulaşılmıştır: KSB kredi hacmi ile KSB'lerde takibe dönüşüm oranı arasında hem kısa hem de uzun dönemde istatistiksel olarak anlamlı bir ilişki olduğu belirlenmiştir. KSB'lerin kredi hacminde, uzun dönemde etkili olan tek değişken takibe dönüşüm oranı iken; kısa dönemde takibe dönüşüm oranı ve döviz kurunun etkili olduğu gözlenmiştir. ÖSB'lerin kredi hacmini etkileyen değişkenlerin araştırıldığı ikinci modelin bulgularına göre uzun dönemde ÖSB'lerde takibe dönüşüm oranı, döviz kuru ve tüketici güven endeksi (TGE) ÖSB'lerin kredi hacmi üzerinde istatistiksel olarak anlamlı etkileri olan değişkenlerdir. Kısa dönemde ise döviz kuru ile bir gecikmeli tüketici güven endeksi ve enflasyon oranı değişkenlerinin ÖSB'lerin kredi hacmini etkilediği belirlenmiştir. Her iki modelde de otokorelasyon, değişen varyans, yapısal kırılma sorunlarının olmadığı testlerle sınandığı için nedensellik bulgularının güvenilir olduğu belirlenmiştir.

Sonuç itibariyle KSB'ler ve ÖSB’lerin kredi verme davranışlarındaki asimetrinin kaynağının döviz kuru ve tüketici güven endeksi olduğu belirlenmiştir. Zira, hem KSB'lerin hem de ÖSB'lerin kredi hacmini negatif yönde etkileyen değişken Kaya ve diğerleri (2016) çalışmalarıyla uyumlu olarak, ilgili grubun takibe dönüşüm oranıdır. Buna göre, ÖSB'lerin kredi hacimlerindeki azalış döviz kurunda yaşanan dalgalanmalar ve ekonomiye ilişkin beklentilerin nispeten kötümser olmasından kaynaklanmaktadır. Aynı makroekonomik yapıda faaliyet gösteren KSB'lerin kredi hacmindeki artışın açıklanabilir ve literatürle uyumlu (Micco ve Panizza, 2006; Brei ve Schclarek 2013; Cull ve Peria, 2013; Coleman ve Feler, 2015, Yeyati vd., 2007; Bertay vd., 2015) tek nedeninin ise üstlendikleri aktif karşı-konjontrürel (döngüsel) rol olduğu düşünülmektedir. 


\section{REFERENCES / KAYNAKLAR}

Alihodžić, A. \& Ekşi, İ. H. (2018). Credit growth and non-performing loans: Evidence from Turkey and some Balkan countries. Eastern Journal of European Studies, 2, 229-249.

Ay Yalçınkaya, A. E. \& Kök, R. (2016). Türk bankacılık sektöründe maliyet etkinliği (2005-2013). Ege Akademik Bakış, 16(2), 273-286.

Bakır Yiğitbaş, Ş. (2012). Bankaların kredi verme davranışı üzerine asimetrik bilginin etkisi ve reel sektör yansıması (Türkiye Analizi 2002-2010) (Yayımlanmış doktora tezi). Kocaeli Üniversitesi, Kocaeli.

Baum, C., Caglayan, M. \& Ozkan, N. (2005). The second moments matter: The response of bank lending behavior to macroeconomic uncertainty. Working Paper, Boston College.

BBC News. (2019). Takipteki alacaklar sorunu neden önemli ve nasıl çözülebilir? Erişim Tarihi: 3.12.2019, https://www.bbc.com/turkce/haberler-dunya-50513836

Behr, P., Norden, L. \& Noth, F. (2013). Financial constraints of private firms and bank lending behavior. Journal of Banking and Finance, 37(9), 3472-3485. https://doi.org/10.1016/j.jbankfin.2013.05.018

Bertay, A. C., Demirgüç-Kunt, A. \& Huizinga, H. (2015). Bank ownership and credit over the business cycle: Is lending by state banks less procyclical? Journal of Banking and Finance, 50, 326-339 https://doi.org/10.1016/j.jbankfin.2014.03.012

Brei, M., \& Schclarek, A. (2013). Public bank lending in times of crisis. Journal of Financial Stability, 9(4), 820830. https://doi.org/10.1016/j.jfs.2013.01.002

Burgess, R. \& Pande, R. (2005). Do rural banks matter? Evidence from the Indian social banking experiment. American Economic Review, 95(3), 780-795. https://doi.org/10.1257/0002828054201242

Coleman, N. \& Feler, L. (2015). Bank ownership, lending, and local economic performance during the 2008-2009 financial crisis. Journal of Monetary Economics, 71, 50-66. https://doi.org/10.1016/j.jmoneco.2014.11.001

Cucinelli, D. (2015). The impact of non-performing loans on bank lending behaviour: Evidence from the Italian banking sector. Eurasian Journal of Business and Economics, 8(16), 59-71. https://dx.doi.org/10.17015/ejbe.2015.016.04

Cull, R. \& Peria, M. S. M. (2013). Bank ownership and lending patterns during the 2008-2009 financial crisis: Evidence from Latin America and Eastern Europe. Journal of Banking Finance, 37(12), 4861-4878. https://dx.doi.org/10.1016/j.jbankfin.2013.08.017

Dell'Ariccia, G., Detragiache, E. \& Rajan, R. (2008). The real effect of banking crises. Journal of Financial Intermediation, 17(1), 89-112. https://doi.org/10.1016/j.jfi.2007.06.001

Demirgüç-Kunt, A. \& Detragiache, E. (1998). Financial liberalization and financial fragility. Working Paper, No. 98/83, Washington: Uluslararası Para Fonu (IMF).

Demirgüç-Kunt, A., Detragiache, E. \& Gupta, P. (2006). Inside the crisis: An empirical analysis of banking systems in distress. Journal of International Money and Finance, 25(5), $702-718$. https://doi.org/10.1016/j.jimonfin.2006.04.004

Dinç, I. S. (2005). Politicians and banks: political influences on government-owned banks in emerging markets. Journal of Financial Economics, 77(2), 453-479. https://doi.org/10.1016/j.jfineco.2004.06.011

Iannotta, G., Nocera, G. \& Sironi, A. (2007). Ownership structure, risk and performance in the European banking industry. Journal of Banking and Finance, 31(7), 2127-2149. https://doi.org/10.1016/j.jbankfin.2006.07.013

Jorda, O., Schularick, M. \& Taylor, A., (2013). When credit bites back. Journal of Money, Credit and Banking, 45(2), 3-28. https://doi.org/10.1111/jmcb.12069 


\section{Kurt Cihangir, Ç.}

Kaya, Z., Şahin, L., Hacıevliyagil, N. \& Ekşi, İ. (2016). Bankaların kredi verme davranışında varlık kalitesinin etkisi. Finansal Araştırmalar ve Çalışmalar Dergisi, 8(14), 147-160. https://doi.org/10.14784/jfrs.52635

Körner, T. \& Schnabel, I. (2011). Public ownership of banks and economic growth-the role of heterogeneity. Economics of Transition and Institutional Change, 19(3), 407-441 https://doi.org/10.1111/j.1468$\underline{0351.2011 .00421 . \mathrm{x}}$

Kurt-Cihangir, Ç. (2019). An empirical evidence on the causality between sectoral economic growth and financial development in Turkey. Gazi Iktisat ve Işletme Dergisi, 5(3), 206-215. https://dx.doi.org/10.30855/gjeb.2019.5.3.006

La Porta, R., Lopez-de-Silanes, F. \& Shleifer, A. (2002). Government ownership of banks. Journal of Finance, 57, 265-301 https://doi.org/10.1111/1540-6261.00422

Maddala, G.S. (2001). Introduction to econometrics (3. Baskl). New York: Wiley.

Mercan, M. (2013). Kredi hacmindeki değişimlerin ekonomik büyümeye etkisi: Türkiye ekonomisi için sınır testi yaklaşımı. Bankacılar Dergisi, 84, 54-71.

Micco, A. \& Panizza, U. (2006). Bank ownership and lending behavior. Economics Letters, 93(2), 248-254 https://doi.org/10.1016/j.econlet.2006.05.009

Mishkin, F. S. (2000). Finansal piyasalar ve kurumlar (İ. Şıklar, A. Çakmak \& S. Yavuz, Çev.). İstanbul: Bilim Teknik Yayınevi.

Narayan, P. K. \& Narayan, S. (2005). Estimating income and price elasticities of imports for Fiji in a cointegration framework. Economic Modelling, 22(3), 423-438. https://doi.org/10.1016/j.econmod.2004.06.004

Olszak, M., Roszkowska, S. \& Kowalska, I. (2018). Macroprudential policy instruments and procyclicality of loan-loss provisions-cross-country evidence. Journal of International Financial Markets, Institutionas and Money, 54, 228-257. https://doi.org/10.1016/j.intfin.2018.01.001

Öztürkler, H. \& Çermikli, A. H. (2007). Türkiye'de bir parasal aktarım kanalı olarak banka kredileri. Finans Politik ve Ekonomik Yorumlar, 44(514), 57-68.

Parasız, İ. (2000). Para banka ve finansal piyasalar (7. Baskl). Bursa: Ezgi Kitabevi Yayınları.

Pesaran, M. H. \& Pesaran, B. (1997). Working with Microfit 4.0: interactive econometric analysis. Oxford: Oxford University Press.

Pesaran, M. H. \& Pesaran, B. (2009). Time series econometrics using Microfit 5.0. New York: Oxford University Press.

Pesaran, M. H. \& Shin, Y. (1999). An autoregressive distrubited lag modeling approach to cointegration analysis (chapter 11). In S. Strom (Ed.), Econometrics and Economic Theory in the 20th Century: The Ragnar Frisch Centennial Symposium. Cambridge: Cambridge University Press.

Pesaran, M. H., Shin, Y. \& Smith, R.J. (2001), Bounds testing approaches to the analysis of level relationships. Journal of Applied Econometrics, 16, 289-326.

Quagliariello, M. (2009). Macroeconomic uncertainty and banks' lending decisions: the case of Italy. Applied Economics, 41(3), 323-336. https://dx.doi.org/10.2139/ssrn.970293

Reinhart, C. \& Kaminsky, G. (1999). The twin crises: The cause of banking and balance of payment problems. American Economic Review, 89(3), 473-500. https://doi.org/10.1257/aer.89.3.473

Reinhart, C. \& Rogoff, K. (2011). From financial crash to debt crisis. American Economic Review, 101(5), 16761706. https://doi.org/10.1257/aer.101.5.1676 
Ruckes, M. (2004). Bank competition and credit standards. Review of Financial Studies, 17(4), 1073-1102. https://doi.org/10.1093/rfs/hhh011

Sapienza, P. (2004). The effects of government ownership on bank lending. Journal of Financial Economics, 72(2), 357-384. https://doi.org/10.1016/j.jfineco.2002.10.002

Stiglitz, J. (1993). The role of the state in financial markets. In proceedings of the World Bank annual conference on economic development, international bank for reconstruction and development/World Bank (ss. 19-56), Washington: DC.

Us, V. (2016). Determinants of non-performing loans in the Turkish banking sector: What has changed after the global crisis? TCMB Araştırma Yayınları Ekonomi Notları, No. 16- 27, 1-14.

Vithessonthi, C. (2016). Deflation, bank credit growth, and non-performing loans: Evidence from Japan. International Review of Financial Analysis, 45, 295- 305. https://doi.org/10.1016/j.irfa.2016.04.003

Yeyati, E. L., Micco, A. \& Panizza, U. (2007). A Reappraisal of state-owned banks. Economia, 7(2), 209-259. 
Kurt Cihangir, Ç.

EK 1. KSBKREDI - ARDL $(1,4,8,1,6,0)$ modeli için tanı testleri

\begin{tabular}{|l|l|l|l|l|}
\hline Test İstatistiği & Uygulanan Test & Olasılık & Ki-Kare & F-İstatistiği \\
\hline Otokorelasyon & Breusch-Godfrey Otokorelasyon LM Testi & 0.9542 & 0.9445 & 0.0469 \\
\hline Değişen Varyans & Breusch-Pagan-Godfrey Testi & 0.3980 & 0.3860 & 1.0597 \\
\hline
\end{tabular}

EK 2. OSBKREDI - ARDL $(1,0,2,2,2,0)$ modeli için tanı testleri

\begin{tabular}{|l|l|l|l|l|}
\hline Test İstatistiği & Uygulanan Test & Olasılık & Ki-Kare & F-İstatistiği \\
\hline Otokorelasyon & Breusch-Godfrey Otokorelasyon LM Testi & 0.9159 & 0.9078 & 0.0879 \\
\hline Değişen Varyans & Breusch-Pagan-Godfrey Testi & 0.5999 & 0.5836 & 0.8492 \\
\hline
\end{tabular}

